\title{
APLIKASI ALGORITMA GREEDY UNTUK PEWARNAAN WILAYAH PADA PETA KOTA PADANG BERBASIS TEOREMA EMPAT WARNA
}

\author{
MUTHIA ZALFA JOFIE, SUSILA BAHRI, AHMAD IQBAL BAQI \\ Program Studi S1 Matematika, \\ Fakultas Matematika dan Ilmu Pengetahuan Alam, Universitas Andalas, \\ Kampus UNAND Limau Manis Padang, Indonesia. \\ email : muthiajofie@gmail.com,susilabahri@gmail.com,ahmadiqbalbaqi@gmail.com
}

Diterima 15 September 2020 Direvisi 14 Oktober 2020 Dipublikasikan 21 Oktober 2020

\begin{abstract}
Abstrak. Kecamatan-kecamatan pada peta kota Padang diwarnai dengan menggunakan algoritma Greedy. Pewarnaan wilayah yang mengasumsikan sebuah kecamatan sebagai simpul dan sisi sebagai penghubung antar kecamatan yang bertetangga tersebut, menggunakan teorema empat warna yang menyatakan banyak warna minimum yang akan digunakan dalam mewarnai peta. Sebelum algoritma Greedy digunakan, graf dual peta tersebut dikonstruksi dan derajat tiap simpul ditentukan. Pada penggunaan algoritma Greedy, himpunan kandidat warna dan inisialisasi solusi dibuat. Selanjutnya, dilakukan pewarnaan pertama kali untuk simpul dengan derajat terbesar, dengan cara memilih secara sebarang warna pada himpunan kandidat. Kemudian, periksa kelayakan dari warna dengan menggunakan prinsip bahwa dua simpul yang bertetangga tidak boleh memiliki warna yang sama. Warna yang dihasilkan kemudian merupakan elemen dari himpunan solusi. Proses pewarnaan tersebut diulangi hingga semua wilayah kecamatan pada peta tersebut diwarnai.
\end{abstract}

Kata Kunci: Algoritma Greedy, Pewarnaan Wilayah, Teorema Empat Warna.

\section{Pendahuluan}

Teori graf merupakan salah satu cabang ilmu matematika yang dapat diaplikasikan untuk membantu menyelesaikan permasalahan sehari-hari. Suatu graf terdiri dari simpul-simpul yang dihubungkan dengan sebuah sisi. Teori graf berhubungan dengan relasi antara simpul dan sisi tersebut.

Salah satu metode dalam teori graf yang digunakan dalam menyelesaikan masalah aplikatif adalah pewarnaan graf. Pewarnaan graf terbagi atas tiga bagian yaitu pewarnaan simpul, pewarnaan sisi, dan pewarnaan wilayah.

Salah satu aplikasi pewarnaan wilayah dari sebuah graf adalah pada pewarnaan peta. Manfaat pewarnaan peta antara lain adalah untuk memperjelas batasan dari wilayah-wilayah yang berbatasan langsung dan juga untuk memperoleh banyaknya

*penulis korespondensi 
warna minimum yang dapat digunakan dalam mewarnai peta. Untuk membedakan wilayah pada peta, dapat digunakan beberapa warna yang berbeda.

Algoritma yang akan digunakan untuk mencari warna minimum pada pewarnaan wilayah graf adalah algoritma Greedy. Algoritma Greedy merupakan algoritma yang digunakan untuk menyelesaikan masalah-masalah optimasi yang memecahkan masalah langkah demi langkah [5]. Dalam pewarnaan wilayah juga didasarkan pada teorema empat warna yang menyatakan bahwa jumlah warna yang dapat digunakan untuk mewarnai suatu wilayah pada peta, tidak lebih dari empat warna [3].

Pada penelitian sebelumnya, Ardiansyah dkk. [1] pada tahun 2010 mengaplikasikan pewarnaan wilayah untuk mewarnai peta provinsi Jawa Timur menggunakan algoritma Greedy yang menghasilkan empat warna. Selanjutnya, Musaffi [4] pada tahun 2015 juga mengaplikasikan pewarnaan wilayah pada peta kota Yogyakarta dengan menggunakan algoritma Greedy berbasis teorema empat warna yang juga menghasilkan empat warna.

Pada penelitian ini, penulis akan mengaplikasikan pewarnaan wilayah dengan menggunakan algoritma Greedy berbasis teorema empat warna yang akan diaplikasikan pada peta kota Padang yang terdiri dari 11 kecamatan.

\section{Landasan Teori}

\subsection{Definisi dan Terminologi}

Suatu graf $G$ didefinisikan sebagai pasangan himpunan $(V(G), E(G))$ dimana $V(G)$ merupakan himpunan tak kosong yang elemen-elemennya dinamakan simpul dari $G$ dan $E(G)$ merupakan pasangan-pasangan tak berurut dari simpul yang disebut sisi dari $G$. Bila terdapat sisi $e$ diantara dua simpul $u$ dan $v$, maka kedua simpul tersebut dinamakan bertetangga. Derajat suatu simpul $v$ di $G$ merupakan banyak sisi yang terkait dengan simpul $v[2]$.

\subsection{Graf Planar}

Suatu graf disebut planar jika graf tersebut dapat digambarkan dalam bidang tanpa adanya sisi yang berpotongan, hanya simpul-simpul ujungnya yang saling berpotongan. Selanjutnya akan dijelaskan mengenai graf dual yang merupakan bagian dari graf planar. Graf dual adalah graf yang terbentuk dari graf planar yang direpresentasikan sebagai graf bidang dengan cara sebagai berikut [2] :

1. Setiap wilayah pada graf planar, buatlah simpul yang menjadi simpul untuk graf dual.

2. Hubungkan dua buah simpul untuk graf dual tersebut dengan sebuah sisi yang menjadi sisi untuk graf dual, dimana sisi tersebut harus memotong setiap sisi pada graf planar.

\subsection{Pewarnaan Wilayah}

Pewarnaan wilayah adalah proses pemberian warna pada tiap wilayah sedemikian sehingga setiap dua wilayah yang bertetangga mempunyai warna yang berbeda. 
Pada pewarnaan wilayah, pewarnaan dapat dilakukan dengan cara mengubah wilayah tersebut membentuk sebuah graf dual, yaitu dengan mengasumsikan suatu area wilayah menjadi satu simpul terlebih dahulu dan menghubungkan dua buah simpul pada dua wilayah yang bertetangga sebagai sisi [3].

\subsection{Teorema Empat Warna}

Teorema 2.1. [6] Setiap graf planar, memiliki empat warna.

\subsection{Algoritma Greedy}

Algoritma Greedy adalah algoritma yang memecahkan masalah langkah demi langkah dan merupakan salah satu metode dalam masalah optimasi [5]. Cara kerja Algoritma Greedy :

1. Membangun himpunan kandidat $C$

Himpunan kandidat $C$ merupakan himpunan yang berisi elemen pembentuk solusi.

2. Inisialisasi himpunan solusi sebagai himpunan kosong.

3. Pilih simpul yang akan diisi warnanya dengan fungsi seleksi simpul.

Fungsi seleksi simpul adalah fungsi yang menyeleksi simpul mana yang akan diwarnai terlebih dahulu. Prioritas pengerjaan simpul dilihat dari simpul yang memiliki derajat terbesar.

4. Memilih kandidat warna dengan menggunakan fungsi seleksi warna.

Fungsi seleksi warna adalah fungsi yang akan memilih warna yang digunakan dalam mewarnai peta.

5. Periksa kelayakan warna yang dipilih menggunakan fungsi kelayakan.

Fungsi kelayakan adalah fungsi yang memeriksa apakah warna layak digunakan untuk sebuah simpul atau tidak. Pemeriksaan kelayakan dapat dilihat dari simpul- simpul yang bertetangga dengan simpul yang akan diwarnai. Ada 2 tahap dalam menentukan kelayakan warna yang akan digunakan pada simpul, yaitu :

a. Dilakukan penyeleksian terhadap himpunan solusi $S$. Jika warna pada himpunan solusi $S$ layak, maka warna tersebut digunakan untuk pewarnaan simpul.

b. Jika tidak ada satupun warna yang layak dari himpunan solusi $S$, maka ambil warna baru dari himpunan kandidat $C$ yang belum pernah digunakan, untuk simpul tersebut. Warna yang layak digunakan untuk simpul terpilih akan dimasukkan ke dalam himpunan solusi $S$, jika warna tidak layak maka proses kembali ke langkah 2.

6. Memasukkan warna menjadi elemen dari himpunan solusi $S$

Himpunan solusi $S$ adalah himpunan yang berisi elemen solusi pemecahan masalah.

7. Periksa apakah solusi sudah meliputi pewarnaan seluruh simpul menggunakan fungsi obyektif

Fungsi obyektif adalah fungsi yang menetapkan sebuah nilai untuk himpunan solusi $S$. Proses pewarnaan selesai jika seluruh simpul sudah diwarnai. 
Jika pewarnaan belum meliputi keseluruhan simpul maka proses kembali ke langkah 2.

\section{Pembahasan}

\subsection{Wilayah Peta Kota Padang}

Berikut ini adalah data kecamatan yang ada di kota Padang beserta simbol simpul untuk setiap kecamatan yaitu :

\begin{tabular}{|c|c|c|}
\hline No. & Kecamatan & Simpul \\
\hline 1. & Koto Tangah & $v_{1}$ \\
\hline 2. & Pauh & $v_{2}$ \\
\hline 3. & Kuranji & $v_{3}$ \\
\hline 4. & Nanggalo & $v_{4}$ \\
\hline 5. & Padang Utara & $v_{5}$ \\
\hline 6. & Padang Barat & $v_{6}$ \\
\hline 7. & Padang Timur & $v_{7}$ \\
\hline 8. & Padang Selatan & $v_{8}$ \\
\hline 9. & Lubuk Begalung & $v_{9}$ \\
\hline 10. & Lubuk Kilangan & $v_{10}$ \\
\hline 11. & Bungus Teluk Kabung & $v_{11}$ \\
\hline
\end{tabular}

Tabel 1. Daftar 11 Kecamatan di Kota Padang Beserta Simpul

Sketsa peta kota Padang beserta simpul pada setiap kecamatan adalah:

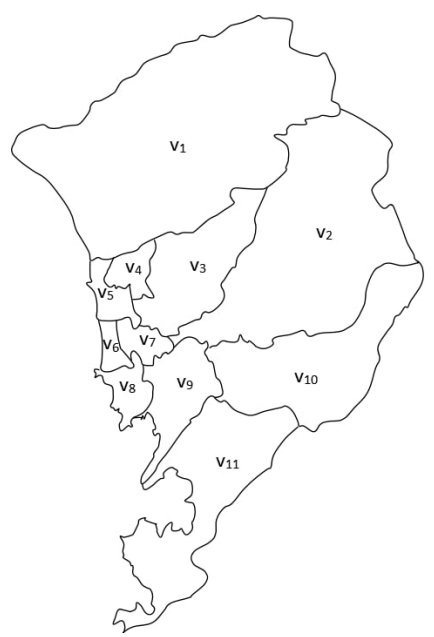

Gambar 1. Peta Kota Padang 


\subsection{Graf Dual dari Peta Kota Padang}

Graf dual dari peta kota Padang dapat dibuat dengan cara merepresentasikan setiap wilayah kecamatan di kota Padang sebagai simpul dan jika dua kecamatan saling bertetangga, maka di graf dualnya, kedua simpul yang bertetangga mempunyai sisi yang menghubungkan kedua simpul tersebut. Representasi graf dual dari peta kota Padang adalah sebagai berikut :



Gambar 2. Graf Dual dari Peta Kota Padang

Pewarnaan simpul dari graf dual $G=(V, E)$ dimana

$V=\left\{v_{1}, v_{2}, v_{3}, v_{4}, v_{5}, v_{6}, v_{7}, v_{8}, v_{9}, v_{10}, v_{11}\right\}$

$E=\left\{v_{1} v_{2}, v_{1} v_{3}, v_{1} v_{4}, v_{1} v_{5}, v_{2} v_{3}, v_{2} v_{7}, v_{2} v_{9}, v_{2} v_{10}, v_{3} v_{4}, v_{3} v_{5}, v_{3} v_{7}, v_{4} v_{5}, v_{5} v_{6}, v_{5} v_{7}, v_{6} v_{7}\right.$ $\left.v_{6} v_{8}, v_{7} v_{8}, v_{7} v_{9}, v_{8} v_{9}, v_{9} v_{10}, v_{9} v_{11}, v_{10} v_{11}\right\}$

untuk peta kota Padang dapat dilakukan dengan menggunakan algoritma Greedy. Selanjutnya ditentukan derajat setiap simpul pada graf dual kota Padang yang diurutkan dari yang terbesar ke yang terkecil.

\subsection{Pewarnaan Wilayah pada Peta Kota Padang Menggunakan Algoritma Greedy Berbasis Teorema Empat Warna}

Langkah-langkah yang dilakukan untuk pewarnaan peta kota Padang dengan algoritma Greedy berbasis teorema empat warna adalah :

Langkah pertama yang akan dilakukan pada pewarnaan peta kota Padang adalah membangun himpunan kandidat warna $C$. Himpunan kandidat warna $C$ yang akan digunakan untuk mewarnai peta kota Padang terdiri dari empat warna yaitu $C=\{$ merah, kuning, hijau, biru $\}$.

Langkah kedua yang akan dilakukan adalah menginisialisasi himpunan solusi $S$ menjadi himpunan kosong, karena belum ada warna yang digunakan pada tahap ini. Himpunan solusi $S$ menjadi $S=\{\}$. 


\begin{tabular}{|c|c|c|c|}
\hline No. & Kecamatan & Simpul & Derajat \\
\hline 1. & Padang Timur & $v_{7}$ & 6 \\
\hline 2. & Pauh & $v_{2}$ & 5 \\
\hline 3. & Kuranji & $v_{3}$ & 5 \\
\hline 4. & Padang Utara & $v_{5}$ & 5 \\
\hline 5. & Lubuk Begalung & $v_{9}$ & 5 \\
\hline 6. & Koto Tangah & $v_{1}$ & 4 \\
\hline 7. & Nanggalo & $v_{4}$ & 3 \\
\hline 8. & Padang Barat & $v_{6}$ & 3 \\
\hline 9. & Padang Selatan & $v_{8}$ & 3 \\
\hline 10. & Lubuk Kilangan & $v_{10}$ & 3 \\
\hline 11. & Bungus Teluk Kabung & $v_{11}$ & 2 \\
\hline
\end{tabular}

Tabel 2. Nilai Derajat dari Setiap Simpul 11 Kecamatan di Kota Padang

Langkah ketiga adalah memilih simpul yang akan diwarnai. Simpul yang akan diwarnai terlebih dahulu adalah simpul yang memiliki derajat terbesar yaitu simpul $v_{7}$.

Langkah keempat adalah memilih warna yang akan digunakan untuk simpul $v_{7}$. Warna pertama dipilih dari himpunan kandidat $C$ yaitu warna merah.

Langkah kelima adalah memeriksa kelayakan warna merah pada himpunan simpul $v_{7}$. Karena simpul $v_{7}$ bertetangga dengan 6 simpul yang belum diwarnai, maka simpul $v_{7}$ layak diberi warna merah.

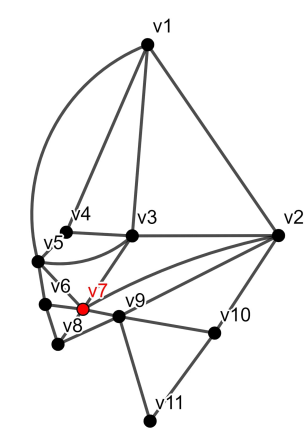

Gambar 3. Pewarnaan untuk Simpul $v_{7}$

Langkah keenam adalah memasukkan warna merah yang digunakan untuk simpul $v_{7}$ kedalam himpunan solusi $S$. Himpunan solusi $S$ menjadi $S=\{$ merah $\}$.

Langkah ketujuh adalah menggunakan fungsi obyektif dalam memeriksa pewarnaan semua simpul. Karena pewarnaan belum meliputi seluruh pewarnaan simpul dan simpul yang telah diwarnai baru satu simpul yaitu simpul $v_{7}$, maka proses akan kembali ke tahap fungsi seleksi simpul.

Untuk simpul yang akan diwarnai selanjutnya, akan dilakukan langkah-langkah 
dari langkah ketiga sampai langkah ketujuh sama seperti simpul sebelumnya. Setelah seluruh simpul diwarnai, maka proses selesai dan diperoleh himpunan solusi $S$ adalah $S=\{$ merah, kuning, hijau, biru $\}$. Berikut ini adalah hasil yang diperoleh untuk pewarnaan seluruh simpul :

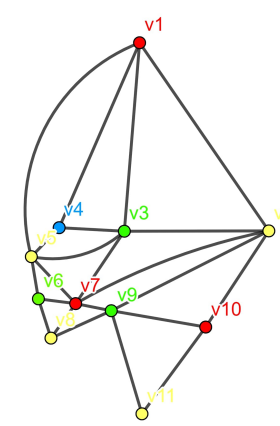

Gambar 4. Pewarnaan Untuk Seluruh Simpul

Optimasi pada penelitian ini adalah proses pada langkah-langkah dalam mewarnai setiap kecamatan pada peta kota Padang, dengan fungsi tujuan yaitu warna yang dihasilkan dalam mewarnai peta kota Padang adalah 4 warna, dan fungsi kendalanya adalah tidak ada warna yang sama untuk dua simpul yang saling bertetangga. Berdasarkan graf dual peta kota Padang yang telah diperoleh, ada 4 simpul yang saling bertetangga yaitu simpul $v_{1}, v_{3}, v_{4}$, dan $v_{5}$. Oleh karena itu, berdasarkan graf dual yang telah diperoleh, maka warna yang diperlukan untuk mewarnai setiap kecamatan pada peta kota Padang paling sedikit 4 warna dan dengan 4 warna cukup untuk mewarnai setiap kecamatan pada peta kota Padang tersebut. Diperoleh bilangan kromatik yaitu $\chi(G)=4$.

Dari hasil pewarnaan simpul untuk peta kota Padang tersebut diperoleh hasil sebagai berikut:

Representasi masing-masing warna adalah sebagai berikut:

a. Warna merah merepresentasikan 3 kecamatan, yaitu Koto Tangah, Padang Timur, dan Lubuk Kilangan.

b. Warna kuning merepresentasikan 4 kecamatan, yaitu Pauh, Padang Utara, Padang Selatan, dan Bungus Teluk Kabung.

c. Warna hijau merepresentasikan 3 kecamatan, yaitu Kuranji, Padang Barat, dan Lubuk Begalung.

d. Warna biru merepresentasikan kecamatan Nanggalo.

\section{Kesimpulan}

Berdasarkan hasil pembahasan sebelumnya, maka dapat disimpulkan bahwa dengan menggunakan algoritma Greedy warna yang diperlukan untuk mewarnai setiap kecamatan pada peta kota Padang cukup dengan 4 warna, dan berdasarkan 


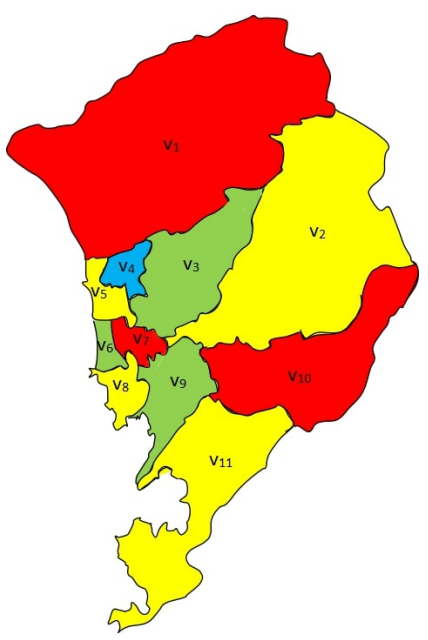

Gambar 5. Peta Kota Padang yang Telah Diwarnai

graf dual yang dihasilkan, setiap kecamatan pada peta kota Padang juga cukup diwarnai dengan 4 warna. Oleh karena itu, setiap kecamatan pada peta kota Padang dapat diwarnai dengan 4 warna yang bersesuaian dengan teorema empat warna. Setiap 2 kecamatan yang bertetangga diberikan warna yang berbeda.

\section{Ucapan Terima kasih}

Penulis mengucapkan terimakasih kepada Ibu Lyra Yulianti, Ibu Arrival Rince Putri, dan Ibu Ferra Yanuar yang telah memberikan masukan dan saran sehingga penelitian ini dapat diselesaikan dengan baik.

\section{Daftar Pustaka}

[1] Ardiansyah, dkk. 2010. Implementasi Algoritma Greedy Untuk Melakukan Graph Coloring: Studi Kasus Peta Propinsi Jawa Timur. Jurnal Informatika Vol. 4 No.1 : $440-448$

[2] Bondy, J.A.,U.S.R. Murty. 1976. Graph Theory with Application. Elsevier Science Publishing, New York

[3] Bryant, V. 1993. Victor Aspects of Combinatorics. Cambridge University Press, New York

[4] Mussafi, N.S.M. 2015. Penerapan Greedy Coloring Algorithm Pada Peta Kotamadya Yogyakarta Berbasis Four-Colour Theorem. Jurnal Kaunia Vol. X No.1 $: 19-26$

[5] Rosen, K.H. 2019. Discreate Mathematics and Its Applications Eighth Edition. McGraw-Hill Education, New York

[6] Xiang, L. 2009. A Formal Proof of The Four Color Theorem. arXiv preprint arXiv:0905.3713. 